\title{
Primary and Secondary Igapó Forests in the Peruvian Amazon: Floristics, Physical Structure and the Predictive Value of Soil Bulk Density
}

\author{
Randall W. Myster ${ }^{1}$ \\ ${ }^{1}$ Biology Department, Oklahoma State University, Oklahoma City, OK 73107, USA \\ Correspondence: Randall W. Myster, Biology Department, Oklahoma State University, Oklahoma City, OK \\ 73107, USA. E-mail: myster@okstate.edu
}

Received: November 7, 2018

Accepted: November 23, 2018 Online Published: January 27, 2019

doi:10.5539/jps.v8n1p20

URL: https://doi.org/10.5539/jps.v8n1p20

\begin{abstract}
Igapó forests are a key part of the Amazon. And so, it is important to know their floristics and physical structure, and how they may be influenced by their soil. The floristics and physical structure of 16 primary $\left[1^{\circ}\right]$ and secondary $\left[2^{\circ}\right]$ igapó forest plots in Loreto Province, Peru was described and linear regressions were computed to explore whether soil bulk density could predict structural parameters. In the $1^{\circ}$ forest, Fabaceae, Malvaceae and Rubiaceae were the most common families and Calycophyllum spruceanum, Ceiba samauma, Inga spp., Cedrela odorata, Copaifera reticulata, Phytelephas macrocarpa, Guazuma rosea, and Piptadenia pteroclada were the most common species. And as flooding increased, bulk density, stem density, stem size, species richness, Fishers $\alpha$, basal area and above-ground biomass all decreased. In the $2^{\circ}$ forest, Urticaceae, Rubiaceae and Euphorbiaceae were the most common families and Cecropia membranacea, Sapium glandulosum, Pourouma guianensis and Byrsonima arthropoda were the most common species. The number of stems was greatest in the island $2^{\circ}$ forest and lowest in the $1^{\circ}$ forest under water for more than four months, and mean stem size, species richness, Fishers $\alpha$, basal area and above-ground biomass was lowest in the sandy beach $2^{\circ}$ forest and highest in the $1^{\circ}$ forest under water one to two months. Soil bulk density predicted mean stem size, species richness and Fishers $\alpha$ well, where all three decreased as soils became more sandy. I conclude that as soil becomes less sandy with more clay content there is an increase in forest structural complexity, unpredictable flooding in $2^{\circ}$ forests reduces structure more than the predictable flood pulse $1^{\circ}$ forests receive, and soil bulk density may have a causal role for diversity in igapó forests.
\end{abstract}

Keywords: island, oxbow lake, river margin, sandy beach, side creek

\section{Introduction}

The Amazon contains several of the ecosystems most important to life on earth and the relationship between their vegetation and soils are key to understanding them (Baudoin, et al., 2003; Haichar et al., 2008; Lauber et al., 2008). Indeed, many Amazon forests have their own unique soils (Pitman et al., 2001; Tuomisto et al., 2003), for example non-flooded terra firme forest is found on clay/loam soils, non-flooded white sand forest is found on soils with a large amount of quartz, and non-flooded palm forest is found on water-logged clay soils (Tuomisto et al., 2003; Myster, 2017). Flooded forests also cover much of the Amazon (Junk, 1989), and include flooding that is due to "black" water defined as nutrient poor forest runoff. Igapó forests occur in those flooded areas (Junk, 1989; Parolin et al., 2004; Honorio, 2006) and an important distinction is between $1^{\circ}$ igapó forests - subject to regular, predictable flood pulses - and $2^{\circ}$ igapó forests - subject to more irregular, unpredictable flooding events (Ferreira, 1997; Ferreria, 2000; Wittman et al., 2010). Both $1^{\circ}$ and $2^{\circ}$ igapó have low diversity and reduced physical structure compared to other Amazon forests (Ruokolainen et al., 2007; Myster, 2009; Myster, 2018a; Myster, 2018b;Myster, 2018c).

Studies have shown that among igapó soil parameters, soil bulk density may be particularly important in determining igapó floristics and physical structure (Haugaasen \& Peres, 2006; Wittman et al., 2010). Soil grain sizes in igapó are of utmost importance, because there are floristic differences depending on whether the substrate is sandy or clay (F. Wittmann, pers. comm.), that is soil bulk density being inversely correlated with the ability of the soil to retain water and nutrients (Parker, 2010). Thus, floristic and physical structural patterns that 
correspond to gradients of soil bulk density - from sandy soils (with their relatively large particles and higher bulk density) to loam soils (with medium size particles and medium bulk density) to clay soils (with small particles and low bulk density) - could be due to variation in water and nutrient retention capacity.

And so, in order to better understand the floristics and physical structure of both $1^{\circ}$ and $2^{\circ}$ igapó, and to explore which aspects of that structure (if any) can be predicted by soil bulk density, I expanded on my own past plot samplings of Amazon flooded forests (Myster, 2007; Myster, 2010; Myster, 2015; Myster, 2016; Myster, 2018a; Myster, 2018b) by sampling $161^{\circ}$ and $2^{\circ}$ igapó forest plots in the Peruvian Amazon. I first use that sampling data to compile floristics (species, genera, families) and compute physical structure parameters (stem density, mean stem diameter at breast height [dbh], species richness, Fishers $\alpha$, stem dispersion pattern, canopy closure, basal area and above-ground biomass) for each of the igapó forests, and then explore if soil bulk density can predict any of these structural parameters.

\section{Materials and Methods}

\subsection{Study Areas}

The first study area, Sabalillo Forest Reserve (SFR: $3^{\circ} 20^{\prime}$ 3"S, 72 $18^{\prime}$ 6" W: Frederickson et al., 2005; Moreau, 2008: www.projectamazonas.org) was on both sides of the upper Apayacu River, $172 \mathrm{~km}$ east of Iquitos, Peru. SFR is within 25,000 preserved acres and is made up of upper Amazon low, seasonally flooded river basins. Alluvial and fluvial Holocene sediments from the eastern slopes of the Andes dominate the soils. The average temperature is $25.2^{\circ} \mathrm{C}$ and precipitation is $3.3 \mathrm{~m}$ per year (Choo et al., 2007). Both $1^{\circ}$ and $2^{\circ}$ igapó and terra firme forest, palm forest and white sand forest are commonly found at SFR. The rainy season is from November and April.

The second study area is the Area de Conservacion Regional Comunal de Tamshiyacu-Tahuayo (ACRCTT: www.perujungle.com: Myster, 2007; Myster, 2010; Myster, 2015b) located in Loreto Province, 80 miles southeast of Iquitos, Peru $\left(\sim 2^{\circ} \mathrm{S}, 75^{\circ} \mathrm{W}\right)$ with an elevation of $\sim 100 \mathrm{~m}$ above sea level (a.s.l.). The reserve is included in a large Amazon protected area, which has wet lowland tropical rainforest (Holdridge, 1967) of large diversity (Daly \& Prance, 1989). The study site has low, seasonally inundated river basins of the upper Amazon, and is named for the white-water rivers (the Tahuayo and the Tamshiyacu) which form large fringing floodplains (Junk, 1989). The substrate is composed alluvial and fluvial Holocene sediments. The average temperature is $26.5^{\circ} \mathrm{C}$ and rainfall ranges between $2.4-3.0 \mathrm{~m}$ per year. $1^{\circ}$ igapó forests are common and the rainy season occurs from November to April. Common tree species include Calycophyllum spruceanum, Ceiba samauma, Inga spp., Cedrela odorata, Copaifera reticulata, Phytelephas macrocarpa, Guazuma rosea, and Piptadenia pteroclada (Puhakka et al., 1992; Myster 2007).

\subsection{Field Sampling}

In June 2013, my field assistants and I sampled five $2^{\circ}$ igapó forests named for their location - island, oxbow lake, river margin, sandy beach and side creek - close to a black-water river at SFR. We set up two plots of 250 $\mathrm{m}^{2}$ each in each of the five forests, and measured diameter at breast height (dbh) of each tree at least $1 \mathrm{~cm} \mathrm{dbh}$ within each plot. We took the dbh measurement at the nearest low point where the stem was cylindrical and above the buttresses when present. For each tree, we identified its species or genus using the taxonomic sources Romoleroux et al. (1997) and Gentry (1993). We also used the Universidad Nacional de la Amazonia Peruana herbarium and the Missouri Botanical Garden web site <www.mobot.org>. We collected three soil samples at random locations in each plot by driving a 3-inch diameter ring into a depth of $10 \mathrm{~cm}$ and extracting the soil. Back in Iquitos, each soil sample was dried for three 4-minute cycles in a microwave and then weighted. Soil bulk density was then computed for each sample as the weighted soil sample divided by the volume of container, and expressed as $\mathrm{g} / \mathrm{cm}^{3}$.

In June 2001 we sampled two plots of the same size $\left(250 \mathrm{~m}^{2}\right)$, using the same protocol as above (for both plants and soil), in three $1^{\circ}$ igapó which are subject to predictable, annual flooding at the ACRCTT. This design sufficiently samples floristics and physical structure of these forests (data published in Myster, 2007; Myster, 2010; Myster, 2015) and so I reuse that data here to address other questions. One $1^{\circ}$ igapó forest was flooded 1-2 month per year (dry), one $1^{\circ}$ igapó forest was flooded 3-4 months every year (wet) and one $1^{\circ}$ igapó forest was flooded over 4 months per year (very wet). Each tree at least $1 \mathrm{~cm}$ dbh was measured and then identified to species or genus using, again, Romoleroux et al. (1997) and Gentry (1993) and the Universidad Nacional de la Amazonia Peruana herbarium and the Missouri Botanical Garden web site <www.mobot.org>. Comparison of a $1^{\circ} 1$ ha plot at ACRCTT with the smaller $1^{\circ}$ ACRCTT mentioned earlier has shown that the smaller plots are large enough to sample floristics and physical structure well (Myster, 2016). Three soil samples were taken in each plot of the three $1^{\circ}$ forests, using the same protocol as the $2^{\circ}$ forests. 


\subsection{Data Analysis}

Floristic tables of family, genus, and species were compiled giving the total number of stems in each family and the stem size structure for each of the secondary forest plots taken together by forest-type, and a complete species list with the number of stems in each of the five $2^{\circ}$ forests. These parameters were then computed for each of the eight forest-types $\left(1^{\circ}\right.$ igapó under water 1-2 months per year, $1^{\circ}$ igapó under water 3-4 months per year, $1^{\circ}$ igapó under water more than 4 months per year, $2^{\circ}$ igapó island, $2^{\circ}$ igapó oxbow lake, $2^{\circ}$ igapó river margin, $2^{\circ}$ igapó sandy beach, $2^{\circ}$ igapó side creek) sampled from $500 \mathrm{~m}^{2}$ combined plot area (1) total number of stems and the average dbh, (2) species richness and Fisher's $\alpha$ diversity index (procedure in Rosenzweig, 1995), (3) stem dispersion pattern (random, uniform, clumped) computed by comparing plot data to Poisson and negative binomial distributions using Chi-square analysis and, if clumped, using Green's index to find degree of clumping (Ludwig \& Reynolds, 1988), (4) canopy closure using the formula in Buchholz et al. (2004) for tropical trees, (5) total basal area (sum of the basal areas of all individual stems where area $=\pi r^{2}$ and $r=$ the dbh of the individual stem / 2) and (6) above-ground biomass (AGB) using the formula in Nascimento \& Laurance (2010) suggested for Amazon tropical trees of these stem sizes.

Finally, linear regression analysis (SAS, 1985) was performed using soil bulk density as the independent variable and six different structural parameters as the dependent variables. Structural parameters from this study and from previously published data collected at ACRCTT were used (Myster, 2007; Myster, 2010; Myster, 2015). Each regression was graphed and expressed as: (1) the Y-intercept of the best-fit regression line, (2) the slope of that line, (3) the amount of variation explained by that line $\left(\mathrm{R}^{2}\right)$, and (4) the p-value of the best-fit line.

\section{Results}

There were a total of 24 plant families found in the five successional plots (Table 1). Urticaceae was the most common family, but the Rubiaceae and Euphorbiaceae were also common. Cannabaceae, Malvaceae, Meliaceae, Picramniaceae and Quiinaceae had only one stem. Every family but Malpighiaceae, Siparunaceae, Rutaceae and Meliaceae showed a monotonic decline, or a reverse J pattern, in stem number as stems get thicker. There were no stems with a dbh greater than $29 \mathrm{~cm}$ (Table 1).

Table 1. The family and total stems for the 10 secondary forest plots pooled together. Total stems are then divided into dbh size clases truncated to whole $\mathrm{cm}$.

\begin{tabular}{llllll}
\hline Family & total & $1<9 \mathrm{~cm}$ & $10<19 \mathrm{~cm}$ & $20<29 \mathrm{~cm}$ & $\geq 30 \mathrm{~cm}$ \\
\hline Urticaceae & 42 & 39 & 3 & 0 & 0 \\
Rubiaceae & 26 & 23 & 2 & 1 & 0 \\
Euphorbiaceae & 24 & 23 & 1 & 0 & 0 \\
Lauraceae & 14 & 14 & 0 & 0 & 0 \\
Fabaceae & 13 & 12 & 1 & 0 & 0 \\
Malpighiaceae & 11 & 9 & 1 & 1 & 0 \\
Apocynaceae & 10 & 10 & 0 & 0 & 0 \\
Violaceae & 9 & 8 & 1 & 0 & 0 \\
Melastomataceae & 5 & 5 & 0 & 0 & 0 \\
Polygonaceae & 5 & 5 & 0 & 0 & 0 \\
Siparunaceae & 5 & 3 & 1 & 1 & 0 \\
Clusiaceae & 4 & 4 & 0 & 0 & 0 \\
Moraceae & 4 & 4 & 0 & 0 & 0 \\
Eeythropalaceae & 3 & 2 & 1 & 0 & 0 \\
Lamiaceae & 3 & 2 & 1 & 0 & 0 \\
Myrsinaceae & 3 & 3 & 0 & 0 & 0 \\
Nyctaginaceae & 3 & 3 & 0 & 0 & 0 \\
Rutaceae & 3 & 0 & 2 & 1 & 0 \\
Ebenaceae & 2 & 2 & 0 & 0 & 0 \\
Cannabaceae & 1 & 1 & 0 & 0 & 0 \\
Malvaceae & 1 & 1 & 0 & 0 & 0 \\
Meliaceae & 1 & 0 & 1 & 0 & 0 \\
Picramniaceae & 1 & 1 & 0 & 0 & 0 \\
Quinaceae & 1 & 1 & 0 & & 0 \\
\hline & & & & &
\end{tabular}


The most common species found in the five successional plots were Cecropia membranacea, Sapium glandulosum, Pourouma guianensis and Byrsonima arthropoda (Table 2).

Table 2. All species sampled in the 10 secondary forest plots and their number of stems in each forest-type

\begin{tabular}{llllll}
\hline Species & sandy & $\begin{array}{l}\text { oxbow } \\
\text { beach }\end{array}$ & $\begin{array}{l}\text { lake } \\
\text { creek }\end{array}$ & island & $\begin{array}{l}\text { river } \\
\text { margin }\end{array}$ \\
\hline Aegiphila integrifolia & 0 & 0 & 1 & 0 & 2 \\
Alibertia stenantha & 0 & 2 & 0 & 3 & 1 \\
Amphirrhox longifolia & 2 & 0 & 3 & 4 & 0 \\
Aspidosperma excelsum & 0 & 2 & 0 & 0 & 2 \\
Bellucia pentamera & 0 & 0 & 0 & 0 & 1 \\
Byrsonima arthropoda & 4 & 0 & 2 & 5 & 0 \\
Calycophyllum spruceanum & 0 & 2 & 0 & 5 & 0 \\
Cecropia ficifolia & 0 & 0 & 3 & 0 & 2 \\
Cecropia membranacea & 9 & 0 & 3 & 8 & 3 \\
Cedrela fissilis & 0 & 0 & 0 & 0 & 1 \\
Coussarea ampla & 0 & 0 & 0 & 1 & 0 \\
Croton cuneatus & 4 & 0 & 0 & 3 & 0 \\
Diospyros guianensis & 0 & 0 & 1 & 0 & 1 \\
Duroia saccifera & 5 & 0 & 0 & 0 & 2 \\
Endicheria verticillata & 0 & 4 & 2 & 0 & 0 \\
Faramea sessilifolia & 0 & 0 & 0 & 2 & 0 \\
Heisteria spruceana & 0 & 3 & 0 & 0 & 0 \\
Himatanthus bracteatus & 3 & 0 & 0 & 0 & 3 \\
Macrolobium acacifolium & 0 & 5 & 2 & 0 & 0 \\
Miconia spichigeri & 0 & 0 & 0 & 4 & 0 \\
Mollia lepidota & 0 & 0 & 0 & 0 & 1 \\
Neea floribunda & 0 & 3 & 0 & 0 & 0 \\
Perebea longipedunculata & 0 & 0 & 2 & 2 & 0 \\
Picramnia sellowii & 0 & 0 & 0 & 1 & 0 \\
Pleurothyrium parviflorum & 2 & 4 & 0 & 0 & 2 \\
Pourouma guianensis & 0 & 6 & 4 & 0 & 4 \\
Pterocarpus amazonum & 0 & 4 & 0 & 0 & 2 \\
Quiina amazonica & 0 & 0 & 1 & 0 & 0 \\
Randia armata & 0 & 0 & 1 & 0 & 1 \\
Sapium glandulosum & 5 & 0 & 4 & 5 & 3 \\
Siparuna guianensis & 0 & 2 & 0 & 0 & 3 \\
Stachyarrhena spicata & 0 & 0 & 0 & 1 & 0 \\
Stylogyne longifolia & 0 & 0 & 0 & 3 & 0 \\
Trema micrantha & 0 & 0 & 1 & 0 & 0 \\
Triplaris americana & 0 & 0 & 3 & 0 & 2 \\
Vismia macrophylla & 4 & 0 & 0 & 0 & 0 \\
Zanthoxylum spruce & 0 & 3 & 0 & 0 & 0 \\
\hline & & & & & \\
& & 0 & 0
\end{tabular}

Sandy beach soil bulk density was greatest and soil bulk density in the forest under water at least four months was the lowest (Table 3). The island plot had the greatest number of stems (47) and the plot in primary forest under water the smallest (18). Sandy beach mean stem size was lowest but the highest in the forest under water only one month. This was also seen for species richness, Fishers $\alpha$, basal area and AGB (Table 3). 
Table 3. Mean soil bulk density and six structural parameters for all eight forests in their $500 \mathrm{~m}^{2}$ plot. For each primary forest, the number of months under water is also given

\begin{tabular}{lllllllll}
\hline & \multicolumn{3}{l}{ Secondary forests } & \multicolumn{5}{c}{ Primary forests } \\
\hline & $\begin{array}{l}\text { Sandy } \\
\text { beach }\end{array}$ & $\begin{array}{l}\text { Oxbow } \\
\text { lake }\end{array}$ & $\begin{array}{l}\text { Side } \\
\text { creek }\end{array}$ & Island & $\begin{array}{l}\text { River } \\
\text { margin }\end{array}$ & $1-2$ & $3-4$ & $>4$ \\
\hline Bulk density $\left(\mathrm{g} / \mathrm{cm}^{3}\right)$ & 1.31 & 1.03 & 0.91 & 0.90 & 0.70 & 0.68 & 0.63 & 0.59 \\
Number of stems & 39 & 40 & 33 & 47 & 36 & 31 & 29 & 18 \\
mean stem size $(\mathrm{cm})$ & 2.1 & 3.0 & 2.8 & 3.1 & 3.2 & 4.8 & 3.6 & 3.5 \\
species richness & 9 & 12 & 15 & 14 & 18 & 21 & 18 & 14 \\
Fishers $\alpha$ & 25 & 32 & 46 & 40 & 55 & 72 & 70 & 60 \\
basal area $\left(\mathrm{m}^{2}\right)$ & 0.14 & 0.28 & 0.21 & 0.35 & 0.29 & 0.54 & 0.31 & 0.18 \\
above-ground & & & & & & & & \\
biomass $(\mathrm{Mg})$ & 8.21 & 8.35 & 10.12 & 11.55 & 12.36 & 27.14 & 16.21 & 13.52 \\
\hline
\end{tabular}

Linear regression analysis was not significant when stem number was the dependent variable (Y-intercept $=18$, slope $=0.9, R^{2}=0.65, p=0.08$ : Figure 1a) but was significant when mean stem size was the dependent variable $\left(\right.$ Y-intercept $=5.8$, slope $=-3.1, R^{2}=0.82, p=0.03$ : Figure $\left.1 b\right)$.

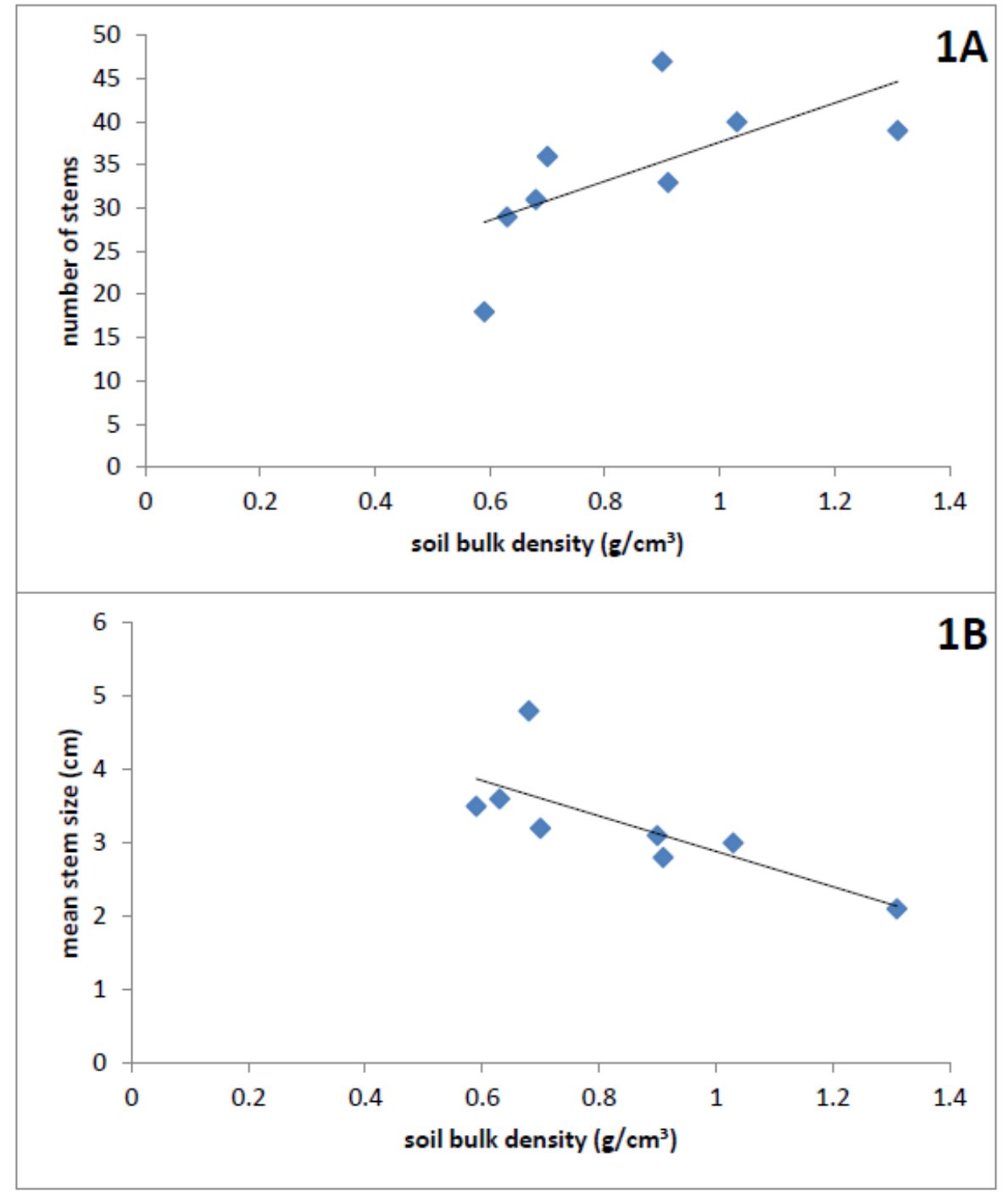

Figure 1. Regression line where (A) number of stems is the dependent variable and soil bulk density is the independent variable, and (B) mean stem size is the dependent variable and soil bulk density is the independent variable 
Linear regression analysis was significant when species richness was the dependent variable (Y-intercept $=26.4$, slope $=-12.2, \mathrm{R}^{2}=0.78, \mathrm{p}=0.04$ : Figure $2 \mathrm{a}$ ) and significant when Fishers $\alpha$ was the dependent variable (Y-intercept $=91.1$, slope $=-25.4, \mathrm{R}^{2}=0.95, \mathrm{p}=0.01$ : Figure $\left.2 \mathrm{~b}\right)$.
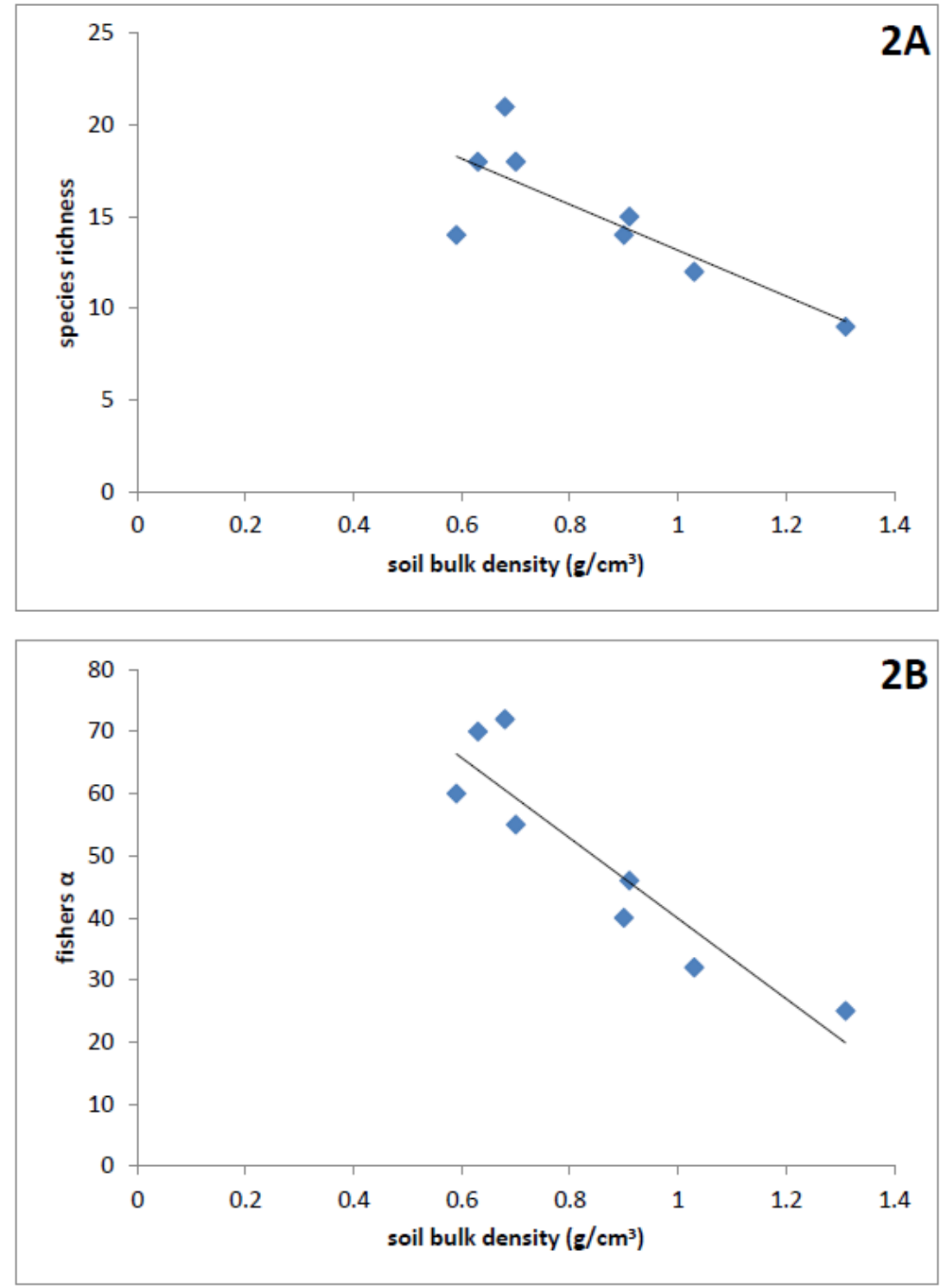

Figure 2. Regression line where (A) species richness is the dependent variable and soil bulk density is the independent variable, and (B) fishers $\alpha$ is the dependent variable and soil bulk density is the independent variable

Linear regression analysis was not significant when basal area was the dependent variable (Y-intercept $=0.49$, slope $=-0.5, \mathrm{R}^{2}=0.42, \mathrm{p}=0.19:$ Figure $\left.3 \mathrm{a}\right)$ and not significant AGB was the dependent variable $(\mathrm{Y}$-intercept $=$ 28.7, slope $=-14.1, R^{2}=0.55, p=0.12$ : Figure $3 b$ ). 


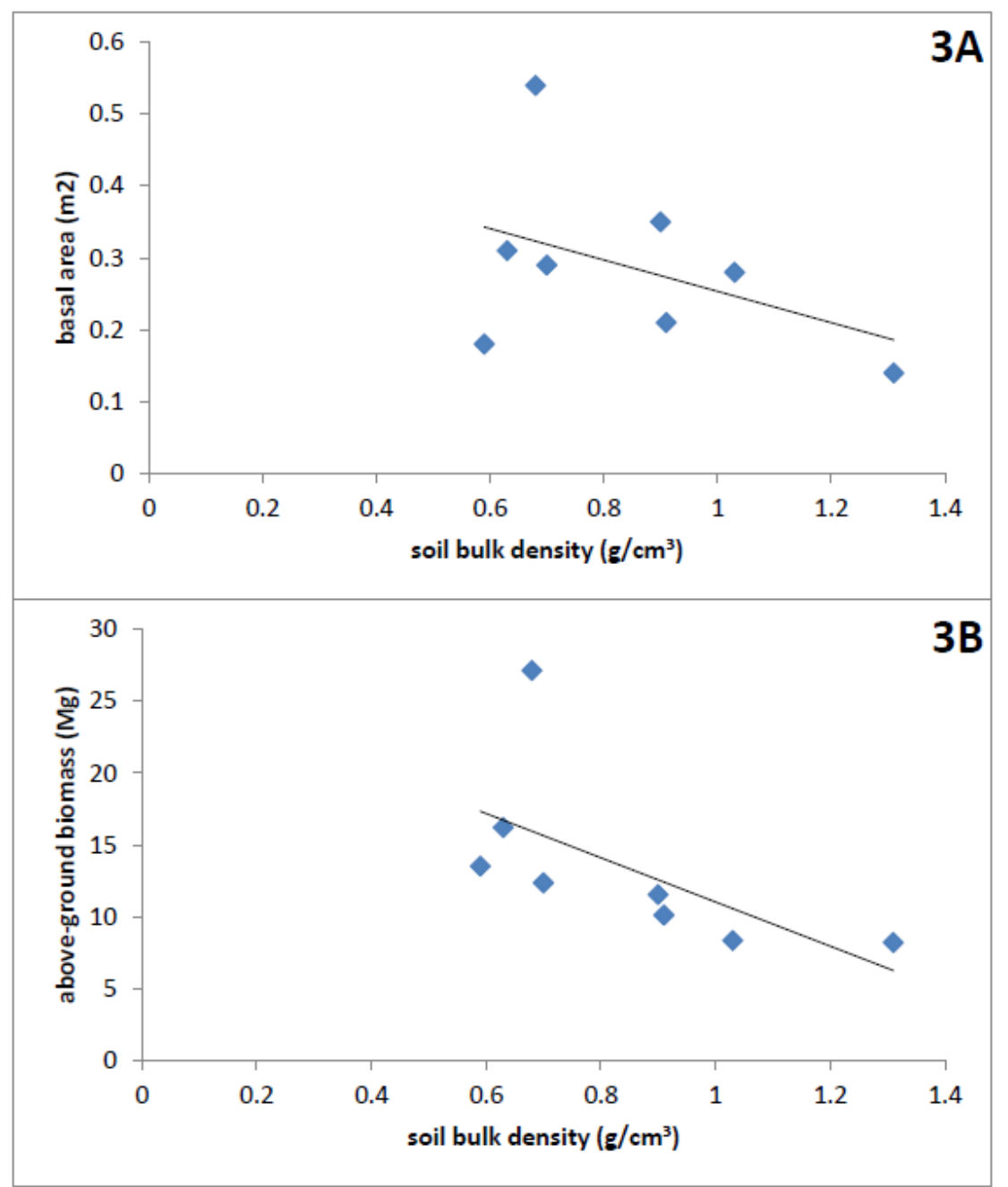

Figure 3. Regression line where (A) basal area is the dependent variable and soil bulk density is the independent variable, and (B) above-ground biomass is the dependent variable and soil bulk density is the independent variable

We see soil bulk density predicted mean stem size, species richness and Fishers $\alpha$ well, and all three decreased as soils became more sandy.

\section{Discussion}

In general, (1) as soil becomes less sandy with more clay content - i.e. increases in water retention capacity and nutrients - there is an increase in forest community complexity, (2) soil bulk density predicted both diversity indexes well from among the forest structural parameters, (3) the unpredictable flooding seen in $2^{\circ}$ forests reduces structure more than the predictable, annual flood pulse that $1^{\circ}$ forests receive, and (4) patterns between soil bulk density and igapó diversity - igapó tree diversity decreases as soils became more sandy - suggest that the ability of these soils to retain water and nutrients is important in determining plant diversity in igapó.

The $1^{\circ}$ forest plots had no species in common with the $2^{\circ}$ forest plots but did have three genera: Niconia, Pourouma and Siparuna. The most common families that the $1^{\circ}$ forest plots had in common with the $2^{\circ}$ forest plots were Fabacae, Rubiacaae and Myriticeae. In the study plots family, genus and species show great similarity with other samplings of similar igapó areas (Ferreira, 1997; Ferreira, 2000) although relative abundances do vary. Gaps within black water forests (Ferreira \& Almeida, 2005; Myster, 2007) however, are quite different from the study plots in $2^{\circ}$ igapó. Sandy beaches, next to black-water rivers, suffer severe drought stress because of low water retention capacity, and their herbaceous vegetation is not well developed, common in black water river systems (Junk, 2011).

In addition to the structural parameters reported here, I also found in the ACRCTT $1^{\circ}$ forests tree stems and 
canopy coverage declined as flooding increased, more so than reductions due to tree-fall, trees were clumped only in the gaps for wet forest, and there were smaller stems in gaps compared to all adjacent forests (Myster, 2007; Myster, 2010; Myster, 2015). Flooding was a greater stressor than the tree-fall, but flooding and tree-fall may present plants with similar cues. There were species in common between wet forests and their gaps and between wet and very wet gaps, and tree richness was highest in dry forest and lowest in very wet gaps. There was also a significant effect of tree-fall gap formation on canopy average height, canopy maximum height (height as measured using a tangent height gauge: Myster, 2010; Myster, 2015), basal area, density, aboveground biomass, turnover, and alpha diversity, and a flooding effect on species richness, genera richness, density, turnover, and alpha diversity. There were fewer but larger trees and more production in the forest plots compared with the gap plots, and the very wet plots had fewer trees, species, and genera compared with the other plots. The most turnover was in the very wet forest, and the wet forest had the greatest richness and alpha diversity. There was also support for a "mass" effect because species from both the non-flooded and most flooded forests and their gaps had overlapping ranges in the less flooded forest and gaps, increasing diversity (Myster, 2007; Myster, 2010; Myster, 2015).

These $2^{\circ}$ forests gain stems (although smaller in size) but lose richness and diversity compared to the floodplain forests which receive regular, annual flooding from black-water rivers. Flooded forests in the Amazon have a greater number of larger trees, and their stem distribution is more normally distributed (not a monotonic decline in numbers with increasing size) leading to fewer trees, genera, and species as flooding increased (Myster, 2010). Flooding eliminates both vertical and horizontal heterogeneity reducing availability of commonly logged tree species and animal populations. The $1^{\circ}$ and $2^{\circ}$ igapó forests are between várzea and palm forest in most of the structural parameters (Myster, 2016). Várzea forests, for example, had more stems, larger stems and more basal area compared to igapó forests with the same duration of flooding. The structure in the $1^{\circ}$ and $2^{\circ}$ igapó forests is less than terra firme forests which have similar clay soils, but are not flooded. Finally results show support for the hypothesis that soil bulk density can predict physical structure in several parameters of the secondary black-water forests. While Tuomisto et al. (2002) reported a negative relationship between soil extractable bases and both plant density and species richness, and Ruokolainen et al. (2007) showed that soil differences explained $50 \%$ of floristic differences among terra firme plots, and geographic distances explained 16\%, patterns between soil bulk density and igapó diversity suggest that the ability of the soils of both $1^{\circ}$ and $2^{\circ}$ igapó forests to retain water and nutrients is important in determining biodiversity of these forests.

\section{Acknowledgements}

I thank Dr. Juan Celedonio Ruiz Macedo of the Universidad Nacional de la Amazonia Peruana and his students Christian Renan Silva Arirama and Josias Tello Huanaquiri, for field and taxonomic assistance. I also thank Devon Michaels at SFR and Alfredo Reyes and Dr. Paul Beaver at ACRCTT for their help. Finally, I thank B. Finegan, I. Turner, H. Asselin, D. Gimenez, C. Lusk, R. Arditi, V. Pillar, M. Bull, M. Holyoak, J.S. Heslop-Harrison, J. Silveira and L. Sandhu for helpful comments on a previous draft.

\section{References}

Baudoin, E., Benizra, E., \& Guckert, A. (2003). Impact of artificial root exudates on the bacterial community structure in bulk soil and maize rhizosphere. Soil Bio. Biochem., 35, 1183-1192. https://doi.org/10.1016/S0038-0717(03)00179-2

Buchholz, T., Tennigkeit, T., \& Weinreich, A. (2004). Maesopsis eminii - a challenging timber tree species in Uganda - a production model for commercial forestry and smallholders. Proceedings of the international union of forestry research organizations (IUFRO) conference on the economics and management of high productivity plantations, Lugo, Spain, 15p.

Choo, J. P. S., Martinez, R. V., \& Stiles, E. V. (2007). Diversity and abundance of plants with flowers and fruits from October 2001 to September 2002 in Paucarillo Reserve, Northeastern Amazon, Peru. Revista Peru. Bio., 14, 25-31.

Ferreira, L. V. (1997). Effects of the duration of flooding on species richness and floristic composition in three hectares in the Jau national park in floodplain forests in central Amazonia. Biodiv. Conser., 6, 1353-1363. https://doi.org/10.1023/A:1018385529531

Ferreira, L. V. (2000). Effects of flooding duration on species richness, floristic composition and forest structure in river margin habitat in Amazonian black-water floodplain forests: implications for future design of protected areas. Biodiv. Conser., 9, 1-14. https://doi.org/10.1023/A:1008989811637

Ferreira, L. V., \& Almeida, S. S. (2005). Relationship between flooding level, plant species diversity and tree fall 
gap size in a seasonally flooded forests in central Amazonia, Brazil. Revista Arvorea, 29, 445-453. https://doi.org/10.1590/S0100-67622005000300012

Frederickson, M. E., Greene, M. J., \& Gordon, D. M. (2005). 'Devil's garden' bedeviled by ants. Nature, 437, 495-496. https://doi.org/10.1038/437495a

Gentry, A. (1993). A field guide to woody plants of northwest South America (Colombia, Ecuador, Peru). Conservation International, Washington, DC.

Haichar, F., Marol, C., Berge, O., Rangel-Castro, J. I., Prosser, J. J., Balesdent, J., Heulin, T., \& Achouak, W. (2008). Plant host habitat and root exudates shape soil bacterial community structure. The ISME Journal, 2, 1221-1230. https://doi.org/10.1038/ismej.2008.80

Haugaasen, T., \& Peres, C. A. (2006). Floristic, edaphic and structural characteristics of flooded and unflooded forests in the lower Rio Purus region of central Amazonina, Brazil. Acta Amazonica, 36, 25-36. https://doi.org/10.1590/S0044-59672006000100005

Holdridge, L. R. (1967). Life zone Ecology. Tropical Science Center, San Jose CR

Honorio, E. N. (2006). Floristic relationships of the tree flora of Jenaro Herrera, an unusual area of the Peruvian Amazon. M. S. thesis, University of Edinburgh, Edinburgh, UK.

Junk, W. J. (1989). Flood tolerance and tree distribution in central Amazonian floodplains. in Holm-Nielsen, L. B., Nielsen, I. C., \& Balslev, H. (Eds.), Tropical forests (pp. 47-64). Botanical dynamics, speciation and diversity Academic press, NY. https://doi.org/10.1016/B978-0-12-353550-4.50012-5

Lauber, C. L., Strickland, M. S., Bradford, M. A., \& Fierer, N. (2008). The influence of soil properties on the structure of bacterial and fungal communities across land-use types. Soil Bio. Biochem., 40, 2407-2415. https://doi.org/10.1016/j.soilbio.2008.05.021

Ludwig, J. A., \& Reynolds, J. F. (1988). Statistical ecology. John Wiley \& sons, NY.

Moreau, C. S. (2008). Unraveling the evolutionary history of the hyperdiverse ant genus Pheidole (Hymenoptera: Formicidae). Mole. Phy. Evol., 48, 224-239. https://doi.org/10.1016/j.ympev.2008.02.020

Myster, R. W. (2007). Interactive effects of flooding and forest gap formation on tree composition and abundance in the Peruvian Amazon. Folia Geobotanica, 42, 1-9. https://doi.org/10.1007/BF02835099

Myster, R. W. (2010). Flooding duration and treefall gap interactive effects on plant community structure, richness and alpha diversity in the Peruvian Amazon. Ecotropica, 16, 43-49.

Myster, R. W. (2015). Flooding x tree fall gap interactive effects on black-water forest floristics and physical structure in the Peruvian Amazon. J. Plant Inter., 10, 126-131. https://doi.org/10.1080/17429145.2015.1029018

Myster, R. W. (2016). The physical structure of Amazon forests: a review. Bot. Rev., 82, 407-427. https://doi.org/10.1007/s12229-016-9174-x

Myster, R. W. (2017). A comparison of the forest soils in the Peruvian Amazon: terra firme, palm, white sand and igapó. J. Soil Sci. Envir. Manag., 8, 30-134.

Myster, R. W. (2018a). What we know about the composition and structure of Igapó forests in the Amazon Basin. Bot. Rev., 84, 356-367. https://doi.org/10.1007/s12229-018-9204-y

Myster, R. W. (2018b). Igapó (black-water flooded forests) in the Amazon basin. Springer-Verlag, Berlin. https://doi.org/10.1007/978-3-319-90122-0

Myster, R. W. (2018c). Effects of soil type on floristics and stand structure in Amazon unflooded forests. J. Plant Studies, 7, 20-28. https://doi.org/10.5539/jps.v7n2p20

Nascimento, H. E. M., \& Laurance, W. F. (2010). Total aboveground biomass in central Amazonian rainforests: a landscape-scale study. For. Ecol. Manag., 157, 1-19.

Parker, R. (2010). Plant \& Soil Science: Fundamentals \& Applications. Cengage Publishers.

Parolin, P., De Simone, O., Hasse, K., Waldhoff, D., Rottenberger, S., Kuhn, U., ... Junk, W. F. (2004). Central Amazonian Floodplain Forests: tree adaptations in a pulsing system. Bot. Rev., 70, 357-380. https://doi.org/10.1663/0006-8101(2004)070[0357:CAFFTA]2.0.CO;2

Pitman, N. C., Terborgh, J. W., Silman, M. R., Nunez, P., Neill, D. A., Ceron, C. E., Palacios, W. A., \& Aulestia, M. (2001). Dominance and distribution of tree species in upper Amazonian terra firme forests. Ecology, 82, 


\section{1-2117. https://doi.org/10.1890/0012-9658(2001)082[2101:DADOTS]2.0.CO;2}

Puhakka, M. E., Kalliola, R., Rajasita, M., \& Salo, J. (1992). River types, site evolution and successional vegetation patterns in Peruvian Amazonia. J. Biogeogra., 19, 651-665. https://doi.org/10.2307/2845707

Romoleroux, K., Foster, R., Valencia, R., Condit, R., Balslev, H., \& Losos, E. (1997). Especies lenosas (dap => 1 $\mathrm{cm}$ ) encontradas en dos hectareas de un bosque de la Amazonia ecuatoriana. In Valencia, R., \& Balslev, H. (Eds.), Estudios Sobre Diversidad y Ecologia de Plantas (pp. 189-215). Pontificia Universidad Catolica del Ecuador, Quito.

Ruokolainen, K., Tuomisto, H., Macia, M. J., Higgins, M. A., \& Yli-Halla, M. (2007). Are floristic and edaphic patterns in Amazonian rain forests congruent for trees, pteridophytes and Melastomataceae?. J. Trop. Ecol., 23, 13-25. https://doi.org/10.1017/S0266467406003889

Rosenzweig, M. L. (1995). Species diversity in space and time. Cambridge University Press, Cambridge UK. https://doi.org/10.1017/CBO9780511623387

SAS Institute. (1985). User's guide: statistics, 5th edition. SAS Institute, Inc. Cary, NC.

Tuomisto, H., Ruokolainen, K., Poulsen, A. D., Moran, R. C., Quintana, C., Canas, G., \& Cell, J. (2002). Distribution and diversity of Pteridophytes and Melastomataceae along edaphic gradients in Yasuni National Park, Ecuadorian Amazonia. Biotropica, 34, 516-533.

Tuomisto, H., Poulson, A. D., Ruokolainen, K., Moran, R. C., Quintata, C., \& Celi, J. (2003). Linking floristic patterns with soil heterogeneity and satellite imagery in Ecuadorian Amazonia. Ecol. Appl., 13, 352-371. https://doi.org/10.1890/1051-0761(2003)013[0352:LFPWSH]2.0.CO;2

Wittmann, F., Schongart, J., \& Junk, W. J. (2010). Phytogeography, species diversity, community structure and dynamics of central Amazonian floodplain forests. In: Junk, W., Piedade, M., Wittmann, F., Schöngart, J., Parolin, P. (Eds.), Amazonian Floodplain Forests (pp. 61-102). Springer, Dordrecht.

https://doi.org/10.1007/978-90-481-8725-6_4

\section{Copyrights}

Copyright for this article is retained by the author(s), with first publication rights granted to the journal.

This is an open-access article distributed under the terms and conditions of the Creative Commons Attribution license (http://creativecommons.org/licenses/by/4.0/). 